\title{
In Vitro Evaluation of Antimicrobial Activity of Coffee Grounds Extracts against Fish Pathogenic Aeromonas hydrophila
}

\author{
Wahyu E. Sari ${ }^{1,2^{*}}$, Muhammad Hambal ${ }^{1,2}$, Henni Vanda ${ }^{1,2}$, Maryulia Dewi ${ }^{1}$, Rumi S. Zamzami ${ }^{1}$, Sukmawan F. \\ Santosa $^{1,2}$, Mudhita Z. Ritonga ${ }^{1}$, Awaluddin Awaluddin ${ }^{1}$, Siti R. Ayuti ${ }^{1}$, Roby Luksmana ${ }^{1}$, Femi J. Sari ${ }^{1}$, Sri Wahyuni $^{1}$ \\ ${ }^{1}$ Faculty of Veterinary Medicine, Universitas Syiah Kuala, 23111 Banda Aceh, Indonesia \\ ${ }^{2}$ Laboratory of Research, Faculty of Veterinary Medicine, Universitas Syiah Kuala, Banda Aceh, Aceh, Indonesia.
}

\begin{abstract}
Fish diseases caused bypathogenic bacteria Aeromonas hydrophila is one of the obstacles for fish farming because it can cause death and loss for farmers. A. hydrophila was reported to possess resistance to several antibiotics. Therefore, there is a need to seek an alternative source of natural antimicrobials. This in vitro study aimed to examinethe effect of ethanol extracts of coffee grounds as an antimicrobial to $A$. hydrophila which infects carp (Cyprinus carpio). The coffee grounds were collected from four traditional coffee shops in Banda Aceh, and a total of $500 \mathrm{~g}$ coffee grounds were extracted using $96 \%$ ethanol. Antimicrobial assay of ethanol extracts of coffee grounds was performed by the agar well diffusion method on Mueller Hinton Agar (MHA) plates. The result showed that all coffee ground extracts at concentration of $10 \%, 50 \%$, and $100 \%$ were able to inhibit A. hydrophila bacteria with the highest inhibition zone of 10.96 $\mathrm{mm}$ posses a strong inhibition, while negative control does not indicate the existence of clear zone. The experiment confirmed the efficacy of coffee ground extracts as natural antimicrobials and suggested the possibility of utilizing them as a drugs for treatment of fish pathogenic caused by A. hydrophila.
\end{abstract}

Keywords: Aeromonas hydrophila, Cyprinus carpio, coffee grounds, ethanol extracts.

\section{Introduction}

Aquaculture in the era of industrialization is increasing rapidly in order to meet human food needs with high nutritional value. The demand for fisheries especially carp (Cyprinus carpio), which is increasingly high, has resulted in communities applying intensive and even super-intensive cultivation systems. The bacterialinduced disease is one of the obstacles to $C$. carpio farming because it can cause death in fish as well as economic losses that are not small for fish farmers. Fish diseases can be caused by parasites, fungi, bacteria, and viruses. Ulcerative disease or ulcer disease which results in the death of approximately 173 tons of carp including $30 \%$ of small fish caused by the bacteria Aeromonas sp. and Pseudomonas sp., can cause losses of around Rp. 126 million [1].

Aeromonas hydrophila is an opportunistic bacterium, Gram-negative, can cause fish death in a very short time to reach $80-100 \%$ [2]. So far, the antibiotics is still widely used to overcome these problems. However, there are many cases of bacterial resistance to antibiotics. Stratev and Odeyemi [3] report that A. hydrophila is resistant to penicillin and ampicillin antibiotics. Other studies also report that Aeromonas sp. resistant to tetracycline antibiotics [4]. Detection of resistant genes in A. hydrophila contaminated $C$. carpio fish using PCR showed that this species was resistant to cefotaxime, ciprofloxacin, vancomycin, and clindamycin antibiotics
(5). Therefore, controlling and treating infectious diseases caused by bacteria that are resistant to antibiotics requires new alternative products that have high potential as antibiotic candidates. Research into antibacterial properties needs to be done to find newantimocrobial products that have the potential to inhibit or kill antibioticresistant bacteria at affordable prices. One alternative that can be taken is to utilize active antibacteriasubstances contained in plants.

Coffee is one of the important export items. During the production period, Indonesia was ranked third after Brazil and Vietnam. On the other hand, the volume of Indonesian coffee exports is ranked in the top three world markets, after Brazil and Columbia. In 2000 and 2010, volume and average coffee exports increased by $4.7 \%$ and $14.7 \%$ respectively [6]. Also, Aceh Province is one of the provinces producing Arabica coffee in Indonesia. The largest coffee-producing area in Aceh Province was in Central Aceh and Bener Meriah Districts. The area of coffee plantations in these two districts reaches 80\% (96 thousand hectares) of the total coffee area in Aceh Province (121. 2 thousand hectares). All of the coffee plantations are smallholder plantations with a total of 77,000 households (KK) in Aceh Province [7]. The number of chemical components in coffee such as caffeine, chlorogenic acid, trigonelline, carbohydrates, fats, amino acids, organic acids, volatile scents, and minerals can produce beneficial effects and endanger the health of coffee lovers [8].

* Corresponding author: wahyueka sari@unsyiah.ac.id 
Other components besides caffeine contained in Robusta coffee beans which are reported to also have antibacterial activity are phenol, trigonelline, and chlorogenic acids. Phenol compounds are flavonoids contained in coffee beans. The biological activity of flavonoids is done by damaging the bacterial cell wall, through differences in polarity between the lipid constituents of DNA and alcohol groups in flavonoid compounds so that the cell wall will be damaged and the compound can enter the nucleus of the bacterial cell. The mechanism of biological activity by flavonoid compounds is different from that carried out by alkaloid compounds, where flavonoids compound damage bacterial cells. Because Aceh is known for its large coffee production, of course, there is coffee waste or coffee ground that is not used well.

It is assumed that coffee grounds extract produce antibacterial compounds that can inhibit the Aeromonas sp, thus can control the bacterial contamination of fish. So far, research on the use of coffee grounds for producing antimicrobial compounds has not been reported. Therefore, the present in vitro studies aimed to evaluate the effect of ethanolic extract of coffee grounds on the bacterium Aeromonas sp inhibition.

\section{Materials and Methods}

\subsection{Coffee grounds sample collection}

The coffee grounds used in this study were collected from four traditional coffee shops in Banda Aceh, a total amount of $500 \mathrm{~g}$. Coffee grounds sampling was randomly carried out in the area. Samples were dried and mashed, then taken onto the laboratory for further analysis.

\subsection{Preparation of ethanolic extract of coffe ground}

A total of $500 \mathrm{~g}$ coffee grounds were extracted using the maceration method. The simplicia powder coffee grounds were inserted into Erlenmeyer, soaked in $225 \mathrm{~mL}$ of $96 \%$ ethanol solution, and covered with aluminum foil. Then, the extract was evaporated using a rotary evaporator to obtain the thick extract. The extract was left at room temperature until all ethanol solvents evaporate. The extracts were weighed and stored in containers closed glass before used for In vitro antimicrobial activity assay

\subsection{In vitro antimicrobial activity assay}

Antimicrobial activities of crude extracts of coffee grounds were tested using the agar diffusion method on paper disc (diameter $=6 \mathrm{~mm}$ ). Coffee ground was dissolved in ethanol $96 \%$ and the different extract concentration of $10 \%, 50 \%$, and $100 \%$ extract were prepared. Each extract concentration was then dropped on a sterilized paper disc. Each paper disc was put on Nutrient Agar (NA) medium which was already been inoculated with $A$. hydrophila bacteria atoncentration of $1 \times 10^{6} \mathrm{cell} / \mathrm{mL}\left(\mathrm{OD}_{620}=0.45\right)$. The positive control used was $5 \mathrm{mg} / \mathrm{mL}$ tetracycline while the negative control was blank paper disc, . Each plate was then incubated at $37{ }^{\circ} \mathrm{C}$ for $24 \mathrm{hrs}$. The clear zone formed around the paper disc indicated the activity of the coffe extract to inhibit microbial growth.

\section{Results and Discussion}

The extracts of coffee grounds with the best antimicrobial activity were extracted using ethanol $96 \%$ solvent. The clear zone formed around paper disc indicated inhibitory activity toward A. hydrophila, indicating that the coffee grounds produced bioactive compounds. The results showed that all extracts $(10 \%, 50 \%$, and $100 \%)$ possess different spectrum inhibitory activity, i.e. extract $100 \%$ showed the highest activity with a diameter of the clear zone was $10.96 \mathrm{~mm}$ (Table 1), while negative control does not indicate the existence of clear zone (Figure 1).

Tabel 1. Antimicrobial activity of different concentration of coffee grounds extract against Aeromonas hydrophila

\begin{tabular}{lccccc}
\hline $\begin{array}{l}\text { Repl } \\
\text { icate } \\
\mathrm{s}\end{array}$ & $\begin{array}{c}\text { Positive } \\
\text { control } \\
(+\end{array}$ & $\begin{array}{c}10 \% \\
\text { concentr } \\
\text { ation } \\
\text { tetracycli } \\
\text { ne })\end{array}$ & $\begin{array}{c}50 \% \\
\text { Concent } \\
\text { ration }\end{array}$ & $\begin{array}{c}100 \% \\
\text { Concent } \\
\text { ration }\end{array}$ & $\begin{array}{c}\text { Negati } \\
\text { ve } \\
\text { contro } \\
1\end{array}$ \\
\hline U1 & 26.08 & 6.32 & 8.02 & 10.53 & $6 \mathrm{~mm}$ \\
& $\mathrm{~mm}$ & $\mathrm{~mm}$ & $\mathrm{~mm}$ & $\mathrm{~mm}$ & \\
$\mathrm{U} 2$ & 26.58 & 6.47 & 8.19 & 11.15 & $6 \mathrm{~mm}$ \\
& $\mathrm{~mm}$ & $\mathrm{~mm}$ & $\mathrm{~mm}$ & $\mathrm{~mm}$ & \\
$\mathrm{U} 3$ & 26.87 & 7.14 & 9.32 & 11.22 & $6 \mathrm{~mm}$ \\
& $\mathrm{~mm}$ & $\mathrm{~mm}$ & $\mathrm{~mm}$ & $\mathrm{~mm}$ & \\
\hline Ave & 26.51 & 6.64 & 8.51 & 10.96 & $6 \mathrm{~mm}$ \\
rage & $\mathrm{mm}$ & $\mathrm{mm}$ & $\mathrm{mm}$ & $\mathrm{mm}$ & \\
\hline
\end{tabular}

According to Davis [9], the criteria for antibacterial activity are as follows: inhibition zone diameter of $5 \mathrm{~mm}$ or less categorized as weak, $5-10 \mathrm{~mm}$ categorized as medium, 10-20 mm categorized as strong, and $20 \mathrm{~mm}$ inhibition zone or more categorized as very strong. Based on these criteria, the antibacterial activity of the coffee ground extractat concentration of $10 \%(6.64 \mathrm{~mm})$ and50\% $(8.51 \mathrm{~mm})$ was medium but at concentration of $100 \%$ $(10.96 \mathrm{~mm})$ was strong. Therefore, tall the concentration of extract coffe used in this study was effective against $A$. hydrophila. Antimicrobial activity of commercial coffee extracts and chemical compounds has been reported as potential natural antimicrobial agents against Salmonella enterica $[10]$.

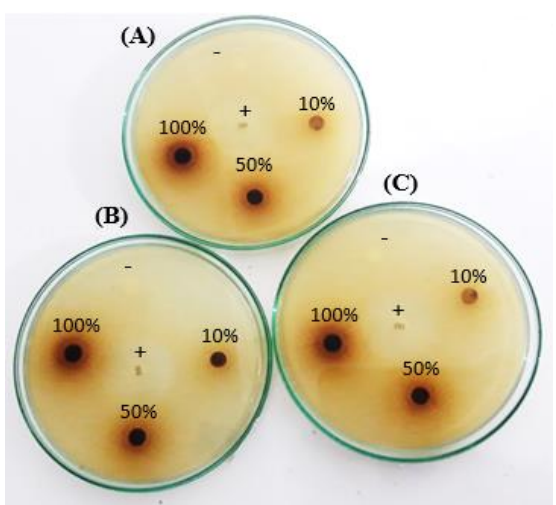

Figure 1. The formation of clear zones around coffee ground extracts after $24 \mathrm{~h}$ incubation at $37{ }^{\circ} \mathrm{C}$. Positive control= tetracycline $5 \mathrm{mg} / \mathrm{mL}$, and negative control= blank paper disc. 


\section{Conclusion}

Ethanol extracts of coffee grounds are capable of inhibiting Aeromonas hydrophila growth in vitro. So, this study confirmed the efficacy of coffee ground extracts as natural antimicrobials and suggested the possibility of utilizing it in drugs for the treatment of fish pathogenic caused by A. hydrophila.

\section{Acknowledgments}

This study was partially funded by PKM-PE Grant from The Ministry of Research, Technology and Higher Education, The Republic of Indonesia 2019. Therefore, we are grateful to The Ministry of Research, Technology and Higher Education, The Republic of Indonesia for funding and supporting this research. We also thanks to Faculty Veterinary Medicine, Universitas Syiah Kuala forproviding the facility.

\section{References}

1. Almeida AA, Farah A, Silva DA, et al.: Antibacterial activity of coffee extracts and selected coffee chemical compouds against enterobacteria. J Agric Food Chem. 2006; 15: 8738-43.

2. Bakhtiari MN, Peyghan R, Monzavi SF : Determination of isolated Aeromonas hydrophila antibiotic resistance profile from farmed common carp (Cyprinus carpio) in Khuzestan Province. Iran Sci Fish J. 2017; 25: 41-50.
3. Baroh I, Setiawan B, Hanani N et al.: Indonesian coffee competitiveness in the international market: review from the demand side. Int J Agr Innov Res. 2014; 3: 2319-1473.

4. Davis WW, Stout TR: Disc plate methods of microbiological antibiotic assay. Microbiology. 1971; 22: 659-665.

5. Farhaty N, Muchtaridi: Tinjauan kimia dan aspek farmakologi senyawa asam klorogenat pada biji kopi : review. J Farm. 2013; 1: 214- 227.

6. Ghenghesh KS, El-Mohammady H, Levin SY, et al. : Antimicrobial resistance profile of Aeromonas species isolated from Libya. Libyan J Med. 2013; 8:21320.

7. Juliaviani N, Sahara, Ratna W : Transmisi harga kopi arabika gayo di Provinsi Aceh. J Agr Indones. 2017; $1: 39-56$.

8. Lukistyowati I, Kurniasih : Detection of aerolysin gen from Aeromonas hydrophila in common carp fed with garlic extract. J Vet. 2012; 13: 43-50.

9. Muslikha, Pujiyanto S, Jannah, SN, et al.: Isolasi, karakteristik Aeromonas hydrophila dan deteksi gen penyebab penyakit motile Aeromonas septicemia (MAS) dengan 16S rRNA dan aerolysin pada ikan lele (Clarias sp.). J Biol. 2016; 5:1-7.

10. Stratev D, Odeyemi OA : Antimicrobial resistance of Aeromonas hydrophila isolated from different food sources: a mini-review. J Infect Pub Health. 2016; 9:535544. 